\title{
The Social Context of Editorials at Medan-Based Newspapers
}

\author{
Sahlan Tampubolon ${ }^{1}$, Amrin Saragih ${ }^{1}$, Eddy Setia ${ }^{1}$, Nurlela ${ }^{1}$ \\ ${ }^{1}$ Post-Graduate Program of Linguistics, Faculty of Cultural Sciences, University of Sumatera Utara, Medan \\ (Indonesia)
}

*Corresponding Author: Sahlan Tampubolon, Post-Graduate Program of Linguistics, Faculty of Cultural Sciences, University of Sumatera Utara, Medan (Indonesia)

\begin{abstract}
This study is aimed to describe how the social context is realized on newspaper editorial's text published in Medan as known as Surat Kabar Terbitan Medan (SKTM). The research is a qualitative descriptive study realized in three topic discussions, they are political topics, state regulators, and social topics. Three newspapers published in Medan which have an editorial were used as the object of research they are Analisa, Sinar Indonesia Baru (SIB), and Waspada. The results show that linguistic realization in terms of using process, participant, circumstance and conjunction, and social context which consists of context of situation, context of culture, and context of ideology show that Medan local newspapers are still enjoying an euphoria of free press from media status quoand adaptating to become a democratic media.The editorial texts are free to criticize a certain phenomenon, and free to criticize the government.
\end{abstract}

Keywords: Social Context, Editorial, Newspapers, Medan

\section{BACKGROUND OF THE STUDY}

Newspapers'editorials can be interpreted as the voice of the newspaper owner to an event or phenomenon that is current news and burgeonin the community(Iedema (1995: 57). The editorial is meant to influence public opinion, thrust critical thinking, and sometimes motivates the readers to take a stand. Dijk in Bell and Garret (1998: 21).

Press freedom in Indonesia differs from capitalist liberal press as adopted by the western press. The Indonesian press is called Pancasila press, while the Western press is called liberal capitalist press. The very basic difference between the two types of press lies on social responsibility to society. The Indonesian press which is called Pancasila press has a social responsibility to society.A news will have a social impact on society while the liberal capitalist press does not. In addition, a society with a liberal press understands and realizes that press work always provided controversial news, so, there is no need for social upheaval in society as a result of press coverage. Anom (2010) stated that From 1984 to 1998, the press publication licence (SIUPP) became the strength in the development of the commercial press which has led to the mushrooming of a free and accountable press. These are the policies which later became an important platform in the formation of Pancasila-based press system under Soeharto's leadership.

Musyafak(1993) stated that Pancasila Press is an issue of continuing interest. Uniformity of reporting was clearly observed in editorial style. Majority of the Indonesiannewspapers during the 1993-1998 period tended to serve more coverage onmiscellaneous, particularly on the development of issues.Most editors preferred to choose a 'middle way' or neutralin criticising government policies and performance. This result illustrated that the presswas 'under siege', curtailed by strict licensing regulations and pre publication penalties.

However, the role of some press in Indonesia that serves as a social control feels not yet fully meet the wishes of the community. This may be due to the loss of integrity of a true journalist. As Journalist, its function and role of the press as social control was lost due to lack of integrity. In addition, the use of language was sometimes too politicized and even dramatized which results in the element of truth being lost. Azlam (2016) described that the content of the Indonesia's news in general during the reform era of 1998 are free to criticize government policy. Then, as media network grows, these media entrepreneurs are now beginning to turn into policy rulers. The news content especially in newspapers began to impress more and more ads, and more news in control. 
It is a question to the society that the Indonesian press is not a liberal press but sometimes its content follows the liberal press. As a consequencies, press in Indonesia become free to report about the privacy, life, and wisdom of a president when such work is usually done by the liberal capitalist press. In addition to being a press officer of the Pancasila, the press in Indonesia should also be able to select newscasts such as violence, murder, film and do not publicize all reports vulgarly.

Hayes(2008) informed that after 1998 when a process of major reforms was introduced, the government scrapped the system of press licences and eventually closed the Ministry of Information. Now, anybody can start a publication, and the number of newspapers and magazines in circulation has jumped from the Suharto-era total of around 400 to over 5,000. "The press is freer than most places in Southeast Asia except the Philippines, but the quality is so low.

Recently, there are implicitly various violations around the news, both in newspaper and electronic media (Massie 2012: 1). The news should be delivered based on the standard method of writing, epistemology, metaphysics, the writing aesthetics, ethical code or the ethics of the press.Some newspapers in small scale published in Medan are found out as not giving enlightenment to their readers. The presented content is dominated by news of murder, rape, infidelity, even stories of pornography. This kind of reporting is not very educated and psychologically will have a negative impact on the reader. However, most of Medan's newspapers are categorized to be wise enough in delivery of the news including the newspaper's main ideas expressed through the editorial.

Santosa, Priyanto, Nuraeni (2014) argues that recently the media in Indonesia are enjoying the situation of the use of language euphoria, where the Indonesian media is still seeking identity to become a democratic media from those previously in a media situation that must follow the situation Political status quo. It is said that one characteristic of an antagonistic media ideology can be seen through the use of transitivity, noun groups, lexis systems, registers and the use of appraisal systems. News is generally delivered in the form of a recording genre but there are times when the media uses exposition genres.

According to Santosa, et.al (2014), in general, there are three types of macro media genres in Indonesia that are used to express the ideology of antagonists. Macro genre consists of news, writings to the editor, and editorial. News is usually written using the reconstruction genre, whereas writing to editors is usually written using exposition genres, and editorial is usually written using the microdiscussion genre. Protagonist news is usually written using the discussion genre, since its genre logically provides space to explore a social issue of counter-conflict on the one hand and support on the other. On the other hand, antagonistic news uses more of the exposition genre, since it provides space to challenge or support the status quo. An antagonist voice typically uses all types of macro and micro genres to oppose or support the status quo. Journalists write their opinions on an issue in the form of orientation followed by clear sequences of events. News of an event can be written by expressing the narratives of journalists even they can also be oriented to the reader's opinion.

\subsection{Research Purpose}

This study aims to describe and explain how how the newspaper editorial published in Medan delivered to the reader in terms of, structure, linguistic realization, and social context.

\section{REVIEW OF LITERATURE}

That is reporters that present an evaluative comment on the word. The consequence of this is that government employees are more likely to convey government policies.Idris (2005) Argued thatusing the framework of 'real-world linguistics', which explains how hidden power is manifested in the 2004 election discourse in Malaysia. 'Real-world linguistics' is an attempt to combine the use of tradition in the 'language world' (which focuses on the language system) with the real use of the so-called 'discourse' in social life.

The general structure of the newspaper's editorials elucidated by Elisabeth Le (2008) in Le Monde's newspaper's editorials. In general,Le Monde's editorialinfluenced the national, European, and International public spheres. Le Monde as a media has a significant roleto its reader. Its role covers not only as a place where some public sphere's interactions can take place,but also it is a full participant in various public spheres with its own values and positions. The application of the proposed framework demonstrated fragments of Le Monde's identity, but for a fuller description of its 
role(s), an enrichment of the framework is required. Besides, Darren Kelsey, Lucy Bennet. (2014)described the realization of discourse, context and power in social media. The results show the importance of understanding 'Individual Communicative Nuance' (ICN) in generating and interpreting online texts. The practice of understanding this context model describes the complexity of the issues posed by the discourse of digital media and technology in the form of synoptic-panoptic, omnioptic or omnoptic of power.

\subsection{Discourse and Texts}

Fairclough (1995: 7) says that discourse is the use of language in the form of social practice, thus, discourse analysis is an analysis of how the text occurs as a sociocultural product. The structure and organization of texts at the level of phonology, grammar, lexical up to a higher level is a domain of discourse analysis related to exchange systems (speech distribution), argument structure, and generic structure. Furthermore, Fairclough (1995: 6) states that the text is a social space in which the social cognition and interaction section simultaneously occur. Text can also be interpreted as an event of sociology (Halliday, 2002: 26). Text is a unit of meaning or semantics that realized by words, phrases, clauses, paragraphs or texts. Webster (2002: 3) described that texts are not always measured by length or not but text is a semantic (meaning) option in a social context; Texts are described as semantic concepts, sociological events.Furthermore, Halliday (2002: 45) elucidated that the text is a semantic concept which means that the text is not composed of sentences but realized in the form of sentences consisting of meanings. Text is a continuous semantic process of choice because text is meaning and meaning is choice, a set of options in the environment of the inverting paradigmatics that make the semantic system.

On the other hand, sociological texts and events are a semantic social process. As a continuous process of having a syntagmantic and paradigmatic relationship. Understanding the phenomenon of discourse as a phenomenon similar to the text is a study and discussion object in this research. In other words, the terms text and discourse are different terms but contain or point to the same phenomenon.

\subsection{Context in Language}

The context of language usage is restricted as anything that is outside the text or use of language. The word context is derived from the word co-meaning together or accompanying, and text is the unit of language, because in principle every unit of language is text. Thus, context refers to anything that accompanies the text. With this understanding, in the Systemic Functional Linguistics (SFL) perspective, the context includes two meanings, namely (1) the linguistic context (so-called internal context) and (2) the social context (also called the external context) (Martin: 1992). Regarding the context in language, Bernwell (2006: 25) defined that social identity theory describes the phenomena in the group (ingroup, and outgroup) based on the view that the identity that is part of a difference that is relative or flexible depends on activities in which a person is engaged in an event or activity. The context in this study is the realization of the use of linguistic elements in the form of grammatical units along with the social context that accompanies an editorial text. The social context, for example, is a combination of the use of linguistic units which includes the structure of the text along with the part of the social context itself, and includes the context of the situation, the cultural context and the ideological context.

\subsection{Social Context}

The relationship between text and context is a semiotic contextual relationship and text determine each other: the context of defining text and text in turn refers to the context. The social context of language usage is limited as anything that accompanies to the use of language or text. The social context is realized in three ways: the context of the situation, the cultural context and the ideological context. Basically, in each interaction the meaning can be expressed in two ways. First, the meaning is encoded by non-verbal realization, such as gestures, facial expressions, or steps, andsecond, the meaning is realized by language. Both realizations of meaning can occur at the same time. (Martin 1992).

\subsection{The Social Context Elements in Text}

Martin (1992), suggests that the social context in a text is manifested in three elements, namely the context of the register, the cultural context (genre), and the ideological context. These three elements 
of the context are embedded and incorporated into text or language and simultaneously form stratified semiotics relationships.

\subsection{Context of situation (Register)}

Context of registerconsists of three parts, namely the component content, participant, and mode. The following three components are described:First, field is a phenomenon of what happens that includes the event of the occurrence of a text and elements or related criteria that bind the process of the occurrence of the text. (Halliday \& Hasan, 1985: 12). The content includes the process or event of the occurrence of a text with the provision whether the event is bound by the rules of an institution or not. The contents (field) itself consists of three aspects, namely: arena / activity, the characteristics of participants or pelibat, and semantic sphere.Second, tenor is a part of the context of situations that discuss who is involved in one interaction. Tenor consists of several elements, namely: formality, status, affection (affection), and contact.Third,modeis how the role of language delivered in an interaction. In other words, does the interaction in delivering the interaction are full of planning, having feedback and what medium or channel is used in the delivery of the interaction.

\subsection{Context of culture}

Context of Cultureis a goal-oriented social activity or event that is done gradually (Martin 1985). The realization of the cultural context includes the three elements of the context of the situation ie component content (field), pelibat (tenor) and mode (mode). That is, the generic structure contained in the cultural context as well has included a discussion of content, pelibat and ways. The cultural context has stages or steps that must be met before the goal. This step or stage is called the term generic structure. Steps or stages in the cultural context are crucial in achieving the social goals of a text. The step or stage is called the text structure (generic or schematic structures).In particular the discussion of the genre, Hyland K (2005: 88) explains that the genre is given by different interactions to different audiences or readers. The discussion of the genre in the metadiscourse is driven by a curiosity about the interpersonal dimension in both academic and professional writing. The genre realization in the media is outlined by Fairclough in Allan Bell (1998: 150) by explaining that the media needs several genres in the delivery of the news. The media uses mixed genres to make news interesting and readers or viewers have a curiosity about an event or event that is happening in the community.

Generally, there are many types of genre as means to measurecultural context (Gerot and Wignel 1994: 190-219).Each genre has its generic structure, has an ideology either explicitly or implicitly. It is recognized or not that ideology greatly influences language. In addition, Lemke (1990: 435) argues that in its use the language always has an ideology that in its use is never neutral. Thus it can be concluded that a text is never separated from the ideological context. Based on the above opinion it can be concluded that the use of text never stand alone without the influence of the ideological value and ideology itself is the embodiment of what has been seen, heard and read before.

\subsection{Context of Ideology}

The following is the context of Ideology which is very influential in actions, ways of thinking and interacting with someone because the ideology has some basic points of discussion such as factors of sex, social class, ethnicity, generation and so forth. (Martin, 1992: 581). The text is the realization of ideology, and ideology can be found in the text.Fairclough (2010: 60) describes that other things to consider deological determination are the features, level of language usage, along with the ideologically related to discourse of power. It is related to the 'meaning' which is sometimes referred to as 'content' in which the meaning is merely a lexical meaning. The lexical meaning of course is important, but equally important in the understanding of the ideology of all aspects of meaning such as presuppositions, implicatures, metaphors, coherence.

Ahmadi, Safeei (2013) analyzed that ideologies are systems of beliefs. These systems of beliefs are shared by members of a social group. The beliefs shared by a group will be called 'social representations' (SRs). Ideologies are the organizing, 'basic' beliefs of these SRs. Ideologies and the social representations organized by them control the social practices of actors as group members. Saeedeh shafiee (2012) defined that Ideology is a system of ideas that shape and gloss over the vast power block of our social life in which language is a medium of ideological delivery. 


\section{RESEARCH METHOD}

Some of Medan's newspapers have an editorial, and some do not. Only newspapers that have editorial namely Daily Newspaper Analisa, New Sinar Indonesia, and Waspada which serve as a source of data to be analyzed. The reason for choosing the three editorials text as source of data because the three newspapers were first published in North Sumatera comparing to the other newspapers and the three newspapers of Medan published had a wider range of readers to the villages in North Sumatra even outside of North Sumatera.Another view related to editorial newspaper in Medan is investigated bySuriyadi et.all (2015). It is Informed that Appraisal analysis in news paper editorial texts in Medan showed that the newspaper editorial texts carried the writer"s position in texts and contexts through evaluative language.The inclination of the pattern of negative engagement by the writers in their newspaper editorial texts portrayed the way to report the negative events, or negation to the events, which were told to the society or the readers of the newspapers

The next stage is done by selecting SKTM editorial text according to the tendency to emerge as an editorial topic. Selection results show topics on politics, state regulator, and social, appear more often and represent the whole editorial topics of SKTM. Another reason for the selection of these three topics is considered to be a current news and growing phenomenon in society. The last data collection technique done in this research is interview. Interviews were conducted to the editorial authors of the three newspapers used as data sources to support or confirm previously obtained data, in particular the results of data analysis of editorial writing structures, social contexts, relating to the ideological context. The result of the interview is used as a triangulation of data to support the previous data.It is the interviewer informed that recently the euphoria of free press in Indonesia really occurs as a result of reformation era.

\section{RESUlt AND DisCUSSION}

In general, the findings resulted in several conclusionsas follows:

a) The types of genre used in editorial text SKTM are genre of analytical exposition, hortatory exposition, review and explanation.

b) Editorial typesare criticizing, explaining or interpreting, persuading but no praising.

c) The material process used is balanced on all three topics. Mental processes, relational identifiers, relational possessiveness are more widely used in political topics, while the use of verbal processes is more widely used in the topic of state organizers, and the behavioral, relational attributive, existential processes are more widely used in social topics. Specific participants are more dominantly used in political topics, while generic participants are more widely used in the topic of state organizers and social topics.

d) Political topics use circumstantial comparisons: differences, while the topics of state organizers use the circumstances because: reasons, and social topics use circumtancebecause: reasons, purposes. Comparison conjunctions: differences are the most dominant conjunctions used in political topics, while conjunctions for reasons are more dominantly used in the topics of state officials, and conjunctions because: reason, and conjunction because: goals are the most dominant conjunctions used in social topics.

e) Political topics use arenas of activities that are (+) institutionalized while topics of state organizers and social topics use arenas of (-) institutionalized activity. The three topics use the characteristics of one participant higher than the other, the (-) formality, the unequal status, and the (+) interpersonal affection. Political topics and social topics realize frequent contacts while topics of state organizers make rare contacts. Political topics conduct positive planning while topics of state and social topics perform (-) planning. The three topics realize positive feedback or time and place, and using writing as medium. Political topics realize the reminding / criticizing ideology, the topics of state organizers and social topics realize the criticism of ideology, reminiscent.

As what Weintraut (2016) described that there are four types of newspaper editorials namely to explain/ to interprete, to criticize, to persuade, to pride, here are types of editorial existed on text editorial SKTM. 
Table1. Types of editorial text SKTM

\begin{tabular}{|c|l|c|c|}
\hline No & Types of editorials & Frequency & Percentage \\
\hline 1 & Criticsm & 5 & $55.6 \%$ \\
\hline 2 & To explain/to Interprete & 2 & $22.2 \%$ \\
\hline 3 & To Persuade & 2 & $22.2 \%$ \\
\hline 4 & To pride & - & - \\
\hline & Total & $\mathbf{9}$ & $\mathbf{1 0 0 \%}$ \\
\hline
\end{tabular}

Related to Linguistic realization in terms of process, participant, actor, circumstance, and conjuction used in text editorial SKTM, the followings are the findings:

Tabel2. Frequency of using Process of Editorial Text SKTM

\begin{tabular}{|l|l|l|}
\hline Types of Process & Frequency & Percentage \\
\hline Material & 93 & $25 \%$ \\
\hline Mental Kognition & 9 & $2.4 \%$ \\
\hline Mental Feeling & 2 & $0.5 \%$ \\
\hline Mental Perception & 12 & $3.2 \%$ \\
\hline Mental Affection & 1 & $0.2 \%$ \\
\hline Relational Ientification & 53 & $14.2 \%$ \\
\hline Relational Attributive & 142 & $38.2 \%$ \\
\hline Relational Possessif & 11 & $3 \%$ \\
\hline Behaver & 10 & $2.7 \%$ \\
\hline Verbal & 16 & $4.2 \%$ \\
\hline Existential & 23 & $6.1 \%$ \\
\hline Total & $\mathbf{3 7 1}$ & $100 \%$ \\
\hline
\end{tabular}

Table3. Partisipan used in editorial text SKTM

\begin{tabular}{|c|c|c|}
\hline Types of Participant & Frequency & Percentage \\
\hline Generic & 4 & $45 \%$ \\
\hline Specific & 5 & $55 \%$ \\
\hline Total & $\mathbf{9}$ & $\mathbf{1 0 0 \%}$ \\
\hline
\end{tabular}

Tabel 4. Types of Actor used in editorial text SKTM

\begin{tabular}{|c|c|c|}
\hline Types of Participant & Frequency & Percentage \\
\hline Human Actor & 46 & 50.5 \\
\hline Non-Human Actor & 45 & 49,5 \\
\hline Total & $\mathbf{9 1}$ & $\mathbf{1 0 0 \%}$ \\
\hline
\end{tabular}

Tabel5. The Circumstances used in editorial text SKTM

\begin{tabular}{|l|c|c|}
\hline \multicolumn{1}{|c|}{ Jenis Sirkumstan } & Frequency & Percentage \\
\hline Circumstan, location, time & 14 & $36 \%$ \\
\hline Circumstan, manner, means & 3 & $7.5 \%$ \\
\hline Circumstan, manner, quality & 7 & $7.5 \%$ \\
\hline Circumstan, cause, goal & 3 & $2.5 \%$ \\
\hline Circumstan, matter & 1 & $2.5 \%$ \\
\hline Circumstan, manner, reason & 1 & $2.5 \%$ \\
\hline Circumstan, spatial, time & 1 & $2.5 \%$ \\
\hline Circumstan, additive, negative & 1 & $10 \%$ \\
\hline Circumstan, cause, reason & 4 & $5.5 \%$ \\
\hline Circumstan, spatial, time & 2 & $5.5 \%$ \\
\hline Circumstan, location, place & 2 & $100 \%$ \\
\hline \multicolumn{1}{c|}{ Total } & 39 & \\
\hline
\end{tabular}

Tabel 6. Types of conjunction used in Editorial text SKTM

\begin{tabular}{|l|l|l|l|}
\hline Types of Conjunction & Example of Conjunction & Frequency & Percentage \\
\hline Spatial, durative & Kemudian (meanwhile), setelah (after) & 3 & $2.8 \%$ \\
\hline Comparative: contrast & Sedangkan(whereas), sebenarnya(actually) & 26 & $23.6 \%$ \\
\hline Cause: reason & Karenanya ( because of) & 31 & $28.1 \%$ \\
\hline Additive: addition & Apalagi, (besides) & 1 & $0.9 \%$ \\
\hline Cause: goal & Sehingga (so), agar (so that) & 23 & $20.9 \%$ \\
\hline Conseqensial: consequent & Jadi(so as),akibatnya(consequently), & 3 & $2.8 \%$ \\
\hline
\end{tabular}




\begin{tabular}{|l|l|l|l|}
\hline & dengan demikian (so), oleh karena (because) & & \\
\hline Condition, : negative & Sayangnya (unfortunately), Jika tidak (if not) & 2 & $1.8 \%$ \\
\hline Condition: positif & Jika (if), maka (so) & 14 & $12.7 \%$ \\
\hline Comparative: equally & Demikian juga (like,as) & 3 & $2.8 \%$. \\
\hline Kondisi: consession & Kalaupun (even if), walaupun (eventhough) & 4 & $3.6 \%$ \\
\hline & Total & 110 & $100 \%$ \\
\hline
\end{tabular}

The social context realizationoccured into three parts, they are context of situation (register), context of culture, and context of ideology.Context of situation is the context that related to who is participant includes field, tenor, and mode. Context of culture is related to the generic structure of the text. Context of Ideology is ways of thinking and interacting occurs in the text.

Tabel 7. Social Context analysis on editorial text SKTM

\begin{tabular}{|c|c|c|c|c|c|}
\hline $\begin{array}{c}\text { Types of Social } \\
\text { Context }\end{array}$ & $\begin{array}{l}\text { Types of } \\
\text { analysisi }\end{array}$ & Sub Analysis & Result & Frequency & Percentage \\
\hline \multirow{20}{*}{$\begin{array}{l}\text { Contextof Situation } \\
\text { (Register) }\end{array}$} & \multirow{8}{*}{ Field } & \multirow{2}{*}{ Types of activity } & (+) Institutionalized & 3 & $33.4 \%$ \\
\hline & & & (-) Institutionalized & 6 & $66.6 \%$ \\
\hline & & \multirow{2}{*}{$\begin{array}{l}\text { Partisipant } \\
\text { characteristic }\end{array}$} & $\begin{array}{l}\text { One participant is higher } \\
\text { than the other }\end{array}$ & 6 & $66.6 \%$ \\
\hline & & & Same participant & 3 & $33.4 \%$ \\
\hline & & \multirow{2}{*}{ Semantic domain } & (+) Spesialisation & 6 & $66.6 \%$ \\
\hline & & & (-) Spesialisation & 3 & $33.4 \%$ \\
\hline & & \multirow{2}{*}{ Formality } & (+) Formal. & 4 & $44.5 \%$ \\
\hline & & & (-) Formal & 5 & $55.5 \%$ \\
\hline & \multirow{6}{*}{ Tenor } & \multirow{2}{*}{ Status } & Not the same & 8 & $88.8 \%$ \\
\hline & & & sama & 1 & $11.2 \%$ \\
\hline & & \multirow{2}{*}{ Affection } & $\begin{array}{l}\text { (+)Interpersonal } \\
\text { affection }\end{array}$ & 9 & $100 \%$ \\
\hline & & & $\begin{array}{l}\text { (-)Interpersonal } \\
\text { affection }\end{array}$ & 0 & - \\
\hline & & \multirow{2}{*}{ Contact (Usuality) } & (+) Always & 7 & $77.8 \%$ \\
\hline & & & (-) Always & 2 & $22.2 \%$ \\
\hline & \multirow{6}{*}{ Mode } & \multirow{2}{*}{ Planning } & (+) Planning & 5 & $55.5 \%$ \\
\hline & & & (-) Planning & 4 & $44.5 \%$ \\
\hline & & \multirow{2}{*}{ Feedback } & (+) Feed back & 9 & $100 \%$ \\
\hline & & & (-) Feedback & 0 & - \\
\hline & & \multirow{2}{*}{ Medium } & Written & 9 & $100 \%$ \\
\hline & & & Oral & 0 & - \\
\hline \multirow{4}{*}{ Context of Culture } & & \multirow{4}{*}{ Generic Structure } & Analitical Exposition & 3 & $33.4 \%$ \\
\hline & & & Hortatory Exposition & 2 & $22.2 \%$ \\
\hline & & & Review & 2 & $22.2 \%$ \\
\hline & & & Eksplanation & 2 & $22.2 \%$ \\
\hline \multirow{4}{*}{ Ideology } & & & Reminding & 3 & $33.3 \%$ \\
\hline & & & Critisizing & 3 & $33.3 \%$ \\
\hline & & & Remind/appealing & 2 & $22.2 \%$ \\
\hline & & & $\begin{array}{l}\text { Offering } \\
\text { solution/appealing }\end{array}$ & 1 & $11.2 \%$ \\
\hline
\end{tabular}

\section{DISCUSSION}

In General, Saragih (1995) claimed that the study of Indonesian newspaper news ideology includes lexicogrammatics, registers, genres and ideologies. on the elements of reality, action and reaction in Indonesian newspapers. Ideologically, the words in Indonesian newspaper news texts present government policies such as definition.After categorizing the results of the above research, the followings are described the discussion.

\subsection{The Structure of the Text Editorials}

The type of SKTM editorial text isdominated by criticizing, then, the genre is dominated by exposition. Using material processes, mental processes and relational processes identifiers, using specific participants, non-human actors, comparison conjunctions, differences, use Arenas of 
activities that are (+) institutionalized, equal status, $(+)$ contact, and (+) planning.If the type of editorial text is critical, the genre used is review, the process used is material, verbal and behavioral process using the generic participants, the human actor, the conjunction of cause, Institutional status, unequal status, (-) contacts, (-) planning, and use using linguistic elements of direct speech and passive voice.

Genres of SKTM text editorial are dominated by exposition either hortatory or analytical, explanation, and review. As stated above that the text of analytic exposition has a social function to express the opinion that a social phenomenon is indeed like that (or not), whereas explanation is an evaluation or a review of an event or event. Gerot and Wignel (1994: 197, 209).

\subsection{Social Context}

Actual use of the social context of SKTM editorial text can be grouped into three parts: the context of situation, the cultural context and the ideological context. The context of a situation is a context that addresses field, tenor and mode, whereas cultural context is the context that discusses the genre, while the context of ideology is the context that discusses how the ideology realized in editorial text.

The findings of the social context of the SKTM editorial text consist of three parts they are context of situation, cultural context, and social context. The context of situation includes field in which it uses an arena of activity that (-) is institutionalized, one participant is higher than the other, the semantic sphere shows that (+) specializes, and (-) formalities The tenor consist of unequal status, interpersonal $(+)$ affection, frequent $(+)$ frequent contacts. Next, modes is realized in $(+)$ planning, $(+)$ distance and place, using the writing medium. The cultural context uses the hortatory exposition genre, analytic exposition, review / criticism, and explanation. The ideological context uses an ideology that is reminiscent of, criticizing, urging.

\subsection{Context of culture}

The cultural context is the context that discusses the type of genre used. At the level of the cultural context, the type of genre used in political topics is the kind of genre of analytic and explanatory exposition, whereas in the topics of state organizers use a kind of genre of analytic exposition, hortatory exposition, review or criticism, and in social topics using a kind of exposition genre of hortatory, Criticism), and explanation.In general, cultural contexts define the configuration of content elements, effects and ways. In other words, the cultural context determines the steps that must be taken to achieve the goal of a text. SKTM in this case write the editorial with step or stage structure of text as follows:

In political topics of SKTM in its editorial dominated by the genre of analytic exposition, it means that editorial texts often invite readers to interpret a social phenomenon by explaining that the event is indeed so. The topic of state organizers uses genres of analytic exposition, hortatory exposition, and review / criticism.Likewise in social topics, editorial texts use types of genre hortatory, reviews (critics), and explanations. This means that the editorial text criticized and commented on the performance of the officials in tackling social events that occurred in the community.

The results in this study corroborate with the results of Santoso's research, Agus, Ardiana (2014), which says that antagonistic news mostly uses exposition genres, since these genres provide space to challenge or support the status quo. Editorial texts mostly use the kind of exposition genre of both analytic exposition and exposition of hortatory wherein the editorial text gives more opinion that a phenomenon, event, or issue is indeed like that and gives opinions or opinions and simultaneously persuades that a phenomenon, Events, issues, should or should not be.

The results of the analysis shows that the structure of editorial textrelated to the types of editorial arecriticizing, explaining/ interpreting, persuading, while the genres used in text editorial are exposition, review, and explaining, and the ideologies using criticism, reminding and appealing. From this findings it can be inferred that the media newspaper in Medan still enjoy euphoria press freedom from the press which is the status quo to a free democratic press. 


\subsection{Context of Ideology}

As has been pointed out earlier that ideology is a value, point of view, position or perspective possessed by someone consciously or not here are the discussion about the ideology of each newspaper.

The writing of a text never stands alone without the influence of its own ideological value. To that end, the following put forward the ideology of each SKTM newspaper along with the expression of ideology in editorial text.
ANALISA
: Generating People's Participation in Development
SIB
: Democracy, Unity and Development
Waspada
: For Truth and Justice

The ideological context in this study is the context that discusses how ideology is realized in editorial text. In the context of ideology in general editorial text realize the ideology with a reminding and criticizing. In the political topics ideology is critical, reminiscent, while the topic of state organizers and ideological social topics is critical, reminiscent. The ideology realized in the SKTM editorial text fits the ideology of each newspaper.

Political topic realizes power by exercising press control on rules and general concencus and realizing a reminiscent ideology. State organizers topic realizes power by exercising press control over rules and norms, and realizing a reminding / criticizing ideology. Social topics realizespress control on habit and norms. The ideology's context is realized by criticizing and offering solutions. Political topics realize the role of giving ionformasi to society. The state organizers topic realizes the role of public observers, critiquing arrogance, and the social topics act as an observers to social phenomena, counselors.

\section{Conclusions}

After a thorough discussion of the analysis, findings and discussions on the realization of structure, linguistic realization, the realization of social context, on the three topics (political, state organizers, social) in the editorial text of SKTM are as the following:

Types of the SKTM editorials are criticizing,explaining/interpreting,persuading,andpriding, while linguistic realization of SKTM's text editorials are:

Related to linguistic realization, political topic dominantly usedmaterial, mental, and relational identification process, while state regulatortopicdominantly used material,verbal process andsocial topic used relational process.Next, participan in political topic was realized in specific participant, whilestate regulatorand social topic used generic participant. Non-humanactor was dominantly used in political and social topic, whilehumanactor was dominantly used in state organizer topic.Circumstances in political topicwere dominantly used circumstance location, timeandcircumstance manner, quality. The state regulator topic used circumstance location, time, and circumstance cause, reason. The social topic used circumstance location, time. The conjuction was realized in political topic were conjuction: comparison, conjuction cause: reason, whilestate regulator topic used conjunction cause, reason and conjunctiom comparison, differences. The social topic used conjunction, cause, purpose, and conjunction cause, reason.

The genre of the SKTM editorials are analitical exposition, Hortatory exposition, review, eksplanation.

Socialcontextare realized in context ofsituation.

Context of situation of SKTMtext editorials are realized in three main parts, they are first, fieldusing an arenas of activities that are (-) institutionalized, participants are one higher than the other participants, semantic domain is (+) specialize, and use formalities that (-) formality. Then, tenor uses unequal status, affection using $(+)$ interpersonal, frequent $(+)$ contacts. Furthermore, modes use $(+)$ planning, $(+)$ distance and place, and use the writing medium. 
The ideological context which is what should be done and not done is realized in the form of an ideology that is reminiscent, critical, appeals.

\section{ACKNOWLEDGEMENTS}

The researcher would like to acknowledge Ministry of research, Technology and Higher education of Republic Indonesia especially the Directorate Research and Community Services for giving fund and scholarship to his study. Besides, He also gave deep gratitude to the Medan Local newspaper editorial's writer as despondence for giving chance to interview them.

\section{REFERENCES}

[1] Ahmadi, H. Safaei, E. Asl. (2013). Editorials and Ideologies. International Journal of Science Culture and Sport (Int JSCS ) 4, (2013), 11-21 On line on (www.iscsjournal.com)

[2] Anom, E. (2010). Policy and Press System in Indonesia 1966-1998. Journal: Jurnal Komunikasi : Malaysian Journal of CommunicationVol.26 Issue 12010.

[3] Azlam, Rhido, AMBO Asse( Perkembangan Surat Kabar di Indonesia) (http://www.ridhoa3.com/2016/01/ perkembangan-surat-kabar-di-indonesia.html 2016 on line May, $3^{\text {rd }}, 2017$

[4] Bell. A. \& Peter G. (1998). Media Discourse. Massachussets : Blackwell publisherLimited.

[5] Eisabeth Le. (2008) Editorials' genre and media roles: Le Monde's editorials from 1999 to 2001. University of Alberta, Modern Languages \& Cultural Studies, 200 Arts Building, Edmonton, Alberta, Canada T6G 2E6. On Line: https://doi.org/10.1016/j.pragma.2008.10.013Get rights and content

[6] Fairclough, N. (2010). Critical Discourse Analysis. Edinburg: Pearson Educated Limited

[7] Fowler, R. \& G.Kress. (1979).Critical Linguistics.In: Fowler, R,B.Hodge, G.Kress \& T.Trew. Language and Control. London: Routledge \& Keagen Paul. P. 185-213

[8] Gerot, L.,Wignell, P. (1994(. Making sense of Functional Grammar.Sydney : Gerd Stabler

[9] Halliday, M.A.K (2002). Linguistic Studies of Text and Discourse. London: Continuum

[10] Halliday, M.A.K.\& Hasan, R. (1985). Language, Context and Text : aspect of language in a social semiotic perspectives. Geelong : Deakin University Press

[11] Hayes, M (2008) An evolving free press in Indonesia. The Phnom Penh Post. Wed, 3 December 2008. On line: http://www.phnompenhpost.com/columns/evolving-free-press-indonesia

[12] Hyland, Ken.2005. Meta Discourse. London : MPG Books Ltd. Bodmin, Cornwall

[13] Idris, A. (2005). Language and power : A Critical Discourse Analysis of the Barisan Nasional's Manifesto in the 2004 Malaysian General Election. Proceedings of the International Conference on Critical Discourse Analysis: Theory into Research, Universiti Kebangsaan Malaysia, Malaysia

[14] Iedema. R. (1995). Media Literacy Report. Sydney : Metropolitan. East Disadvantaged schools program.

[15] Kelsey D., Bennet L.(2014). Discipline and Resistance on Social Media: Inthe PaulChambers 'Twitter Joke Trial' Journal Discourse, power and context 3 (2014) 37-45

[16] Lemke, J.L., (1990). “Technical Discourse and Technical Ideology”. In: Halliday,MAK., J. Gibbons \& H. Nicholas, editors. Learning, Keeping and Using Language.. Makalah Congress on Applied Linguisticsh $8^{\text {th }}$ World Congress on Applied Linguistics. Vol. II. Amstertdam : John Benjamin Publishing, p. 435-460.

[17] Martin, J.R. (1985 a) "Process and Text: Two aspects of Human Semiotics".JD> Beanson \& WS.Greaves,Eds., Systemic Perspectives on Discourse. Vol 1. Norwood, N.J,:MAblex Publishing Corporation.

[18] Martin J.R (1992). English Text: System and Structure. Amsterdam: John Benjamin Publishing Company.

[19] Massie J. (2012). Etika Pers dan Jurnalisme Modern. Pers Bersuara: Minahasa On line : http://swara manadonews.com/?p=3663

[20] Musyafak, N. (1993). Press Freedom in Indonesia An examination of "Press Pancasila" between 19931998. Thesis. Semarang : IAIN Walisongo

[21] Saeedeh Shafiee Nahrkhalaji, (2013) Ideology and Power in Political discourse.Departement of English, Islamic Azad University, najafabad Branch, DaneshgahBoulevard, Najafabad, Isfahan Iran. On line Shafeesaeedeh@yahoo.com

[22] Santosa, R., Agus Dwi Priyanto., Ardiana Nuraeni. (2014) Genre and register of antagonost's Language in Media : An Appraisal Study of Indonesian Newspapers. Kata. A biannual publicationon the study of language and literature. Volume 16, Number 1, June 2014. (23-35).

[23] Saragih, A. (1995). "Discourse Analysis of Indonesian Newspaper Texts: a study of reality, action and reaction" (disertasi). Bundoora, Victoria : La Trobe University. 
[24] Suriyadi, Sinar,T.S., Saragih, A. Setia E.(2015) The Pattern of Engagement in Medan Based Newspapers'Editorial Texts. IOSR Journal Of Humanities And Social Science (IOSR-JHSS) Volume 20, Issue 1, Ver.1(Jan. 2015), On line: www.iosrjournals.org (16-22)

[25] Webster, J.J. 2002. Linguistics Studies of Text and Discourse. New York: Continuum

[26] Weintraut. A. ( 2016 ). Writing editorial. Annandale High School. Annandale, Accessed on 23th May 2016 On line. www.geneseo.edu/ bennett/EdWrite.htm

\section{AUTHORS' BIOGRAPHY}

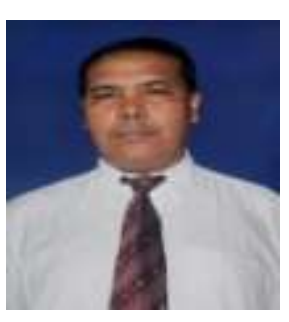

Sahlan Tampubolon, is Doctorate candidate in the Post Graduate Department of Linguistics, Faculty of Cultural Sciences, University of Sumatera Utara (USU), Medan (Indonesia). He works for Nommensen HKBP University Medan since 2013 and his major is Microteaching. His publications are dominantly dealing with Functional Linguistics.

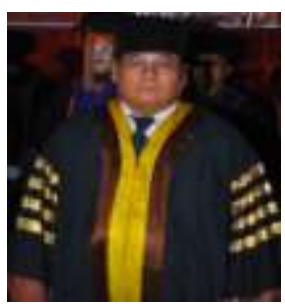

Prof. Amrin Saragih MA, Ph.D, gothis Doctorate Degree in Linguistics fromLa Trobe University at Melbourne, Victoria Australia and becomes visiting professor at the Post Graduate Department of Linguistics, Faculty of Cultural Sciences, USU.He works for the State University of Medan (UNIMED) with special interest in Discourse Analysis and Systemic Functional Linguistics.

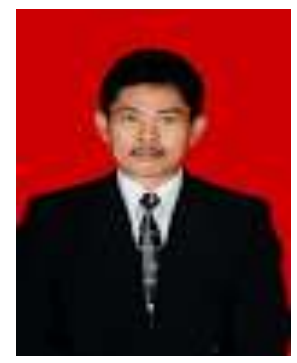

Dr. Eddy Setia, obtained his Doctorate Degree in Linguistics from Udayana State University (UNUD), Bali (Indonesia) and is now head of Post Graduate Department of Linguistics, Faculty of Cultural Sciences, USU. His major concern is related to Intercultural Communication and English as a Second Language (ESL).

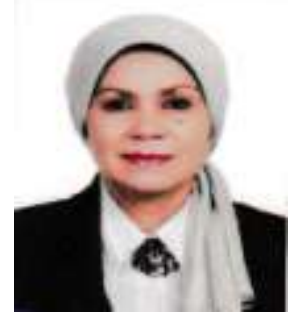

Dr. Nurlelaheld, her Doctorate Degree in Systemic Functional Linguistics from USU. She was ex-secretary of the Post Graduate Department of Linguistics, Faculty of Cultural Sciences, USU.

Citation: Sahlan Tampubolon, et al. "The Social Context of Editorials at Medan-Based Newspapers." International Journal of Humanities Social Sciences and Education (IJHSSE), vol 4, no. 10, 2017, pp. 81-91. doi:http://dx.doi.org/10.20431/2349-0381.0410012.

Copyright: (C) 2017 Authors. This is an open-access article distributed under the terms of the Creative Commons Attribution License, which permits unrestricted use, distribution, and reproduction in any medium, provided the original author and source are credited. 